\title{
Evaluation Of The Admission Characteristics That Predict Students' Final Year Academic Performance: Abuad Experience
}

\author{
Lawal, Yekini Olawaiye (PhD.) \\ Director of Academic Planning/Provost College of Social and Management Sciences \\ Afe Babalola University, Ado Ekiti Nigeria \\ e-mail: lawal9250@yahoo.com
}

\section{Adejuwon, Samuel Oluwaseun (BSc.)}

\author{
Academic Planning Officer \\ Afe Babalola University, Ado Ekiti Nigeria \\ e-mail:adejuwon.samuel@yahoo.com
}

\section{Doi:10.5901/jesr.2014.v4n1p221}

\begin{abstract}
The mandatory requirement for admission into the first year degree programmes for all Nigeria universities and tertiary institutions are the combination of: Secondary School Certificate (SSCE) or equivalent and Universal tertiary matriculation examination (UTME). The validity of these examinations have been subjected to scrutiny because of the poor performance of many of the students at their final year examinations. Hence most universities had introduced the Post UTME examinations to further assess their prospective students. Afe Babalola is one of them. There exist varied findings on the relationship of the various entry qualifications in the universities with students' final year performances. This work examined the academic admission scores of; SSCE, UTME, PUTME and WAITAV as predictors for the performance of the pioneer graduating students. Descriptive statistics, scatter plot, bi-variate correlation matrix and regression analysis were employed using the SPSS V 16 software. The SSCE, PUTME, WGHT and gender had positive significant correlation values of 0.183, 0.1320 .115 and 0.10 respectively with performance. The female performed better. Age and UTME had negative correlation. Since UTME is a bad predictor, yet a government compulsory requirement for admission, universities should continue to combine the UTME and PUTME but assign less weight to the UTME value in the computation WGHTAV. The managers of the UTME must reevaluate the reliability and integrity of the examination.
\end{abstract}

Keywords: Admission, Performance, Predictor, Correlation, Cumulative Grade Point

\section{Introduction}

In the past, individual universities conducted concessional examinations for the selection of their prospective students. Other compulsory condition was the possession of five credit passes in the relevant subjects in the school certificate examination and the general certificate of education at the ordinary level. The other mode of entry was the direct admission of students into the direct second year level of candidates who possessed the sixth form certificate or the general certificate of education at the advanced level in the relevant papers. Problem arose, where students had multiple admissions in several universities and those who could not afford to write admission examinations to multiple institutions and the not too brilliant students were deprived the opportunity of admission into the very limited facilities. These and other problems caused the Federal Government of Nigeria to establish the Joint admission and Matriculation Board (JAMB, 1978). Act No. 2 of 1978 of the Federal Military Government, 13 $3^{\text {th }}$ February, 1978. The body was to provide the National Central Admission System.

Decree (Act) No. 16 of 1985 as amended by Decree (Act) No. 48 of 1988 empowers the National Universities Commission to lay down minimum standards for all programmes taught in Nigerian universities (NUC, 2012). The NUC also has in place curricula that provide universal Benchmark Minimum Academic Standard (BMAS) for all programmes in the universities. Admission criteria into these programmes are stipulated by the National Universities Commission's (NUC). Admission into the first year degree programmes requires that the student meet three mandatory conditions which are:

- possession of five credit passes in English and Mathematics and any other three subjects relevant to the 
students proposed course of study in the Secondary School Certificate Examinations (SSCE) or equivalent, which is conducted by the various organizations of government,

- attainment of the NUC determined minimum score in the University and Tertiary Matriculation Examination (UTME) which is conducted by another government examination body called the Joint Admissions and Matriculation Board (JAMB),

- attainment of the minimum age of 16years.

These criteria were set to ensure universal admission standard for all the universities and tertiary institutions (private and public). To ensure compliance, NUC visits to examine the universities programme before graduation to accredit these programmes. Students' performances are measured by laid standards whose computation results in the cumulative grade point average (CGPA) (Table 1).

Table 1: University Degree Classification

\begin{tabular}{|c|c|c|c|c|}
\hline Class of Degree & 1 & $2^{1}$ & $2^{2}$ & 3 \\
\hline Value Score (CGPA) & $4.5-5.0$ & $3.5-4.49$ & $2.5-3.49$ & $1.5-2.49$ \\
\hline
\end{tabular}

Source: Benchmark Minimum Academic Standard (NUC BMAS, 2012)

There have been serious doubts on the integrity on the conduct of these two examinations; SSCE and UTME. Students, teachers and even agents of the examination bodies have been reported to have been caught in large scale examination malpractices during the conduct of the examinations. Consequently, studies have shown that students who scored high in both examinations had performed very poorly in the universities, final examinations.

It is as a result of these that some universities decided to introduce the post UTME examinations which were conducted by each individual university. The integrity of the Post UTME was well protected as they were conducted inhouse. The universities in respecting the directive of the education ministry decided to supplement the SSCE and UTME results with their Post UTME (PUTME) scores.

\subsection{Problem}

There have been serious doubts on the integrity and validity of these two examinations; SSCE and UTME. Students, teachers and even agents of the examination bodies have been reported to have been caught in large scale examination malpractices during the conduct of the examinations. Consequent upon which, studies have shown that students who scored high in both examinations had performed very poorly in the universities, final examinations. Expanding his study to include other extraneous social variables and academic admission criteria, Parveen Azam Ali (2008) in his study reported that academic factors considered in the admission criteria were better predictors of students' academic performance than the non-academic factors.

\subsection{Purpose of study}

The purpose of the study was to determine the admission predictor that reduce the level of poor performance of undergraduates and reduce the level of attrition consequent upon poor performance and its attendant level of dropouts and prolonged stay in the university.

Afe Babalola University (ABUAD) invited students with the JAMB and NUC approved minimum UTME score and minimum age limit and administered on them its Post UTME. The integrity of the Post UTME was well protected as it was conducted by its staff members in-house. The university in respecting the directive of the NUC and Jamb decided to supplement the compulsory requirement of SSCE and UTME results with the PUTME scores. ABUAD invited students with the JAMB and NUC approved minimum UTME score and minimum age limit and administered on them its PUTME. It integrated the PUTME with UME and obtained a weighted average (WGHTAV).

Those admitted with these criteria have now graduated with varying classes of degrees which were computed using the standard NUC prescribed format for CGPA calculation. This work examined the academic admission scores of; SSCE, UTME, PUTME and WAITAV as predictors for the performance of the graduating students as measured by their Cumulative Grade Point Average (CGPA). It also examined the effects of other social factors on the performance of the graduating students. 


\section{Review of Literature}

There exist varied findings on the relationship of the various entry qualifications in the universities by authors. Barrow et al (2009) investigated three groups of students in the same institution and found that their pre-entry academic achievements significantly influenced the degree performance of the students. In their study, Kolawole et al (2011) had reported very low significant relationship between the UTME scores and CGPA values at all levels. Ajogbeje and Borisade (2013) found a similar situation, positive and significant correlation, though low between CGPA and other admission qualifications as follows: 0.095 and 0.158 between UTME and CGPA and between SSCE and CGPA respectively.

Ezema (2006) compared the degree results of direct entry, UTME and remedial students and concluded that there was no significant difference between the CGPA of the three groups. In a similar study, Emaiku (2012) examined 253 students randomly selected from two universities in Benue state. The sample population also merged both students who entered the university through UTME, remedial and direct entry admissions. He concluded that there was no significant difference in the mean academic achievements of students who were admitted into the university through UTME, remedial programme and direct entry admissions.

Expanding the admission variables, Gbore (2013) combined more admission variables of; SSCE, UTME, National diploma (ND) and National certificate of Education (NCE) which had no common base. While the combination of SSCE and UME was a requirement for admission into the first year class, the ND and NCE were requirements admission to the direct admission into second year level. Gbore (2013) examined the relationship between the cognitive entry characteristics; SSCE, UTME, National diploma (ND) and National certificate of Education (NCE) and CGPA of selected undergraduates from six universities in the South West, Nigeria. He reported that, there was significant correlation between CGPA and SSCE with low correlation between UTME and CGPA and moderate correlation between ND/ NCE and CGPA. Consequently, he recommended ND and NCE as entry qualifications for the year two degree programmes. Gbore's conclusion suggested that students should not be admitted into the first year programmes, a suggestion that negates the 6-3-3-4 educational policy of the Nigerian government.

Contrary to the findings of Osakuade (2011) who reported that PUTME was a better predictor than the UTME and therefore suggested that, JAMB should continue to conduct UTME as pre-qualifying examinations, Ogbebor (2012) found that UTME was a more effective predictor than the PUTME and concluded that, it was a waste of time for universities to conduct individual examinations.

\subsection{Extraneous Intervening Factors}

Some extraneous intervening factors such as methods of teaching, lecture hours, academic and residential environments have been introduced by some authors.

\subsection{Social, Learning and Teaching Environments}

Emaiku (2012) in his study which selected respondents from two different universities did not consider the varied social learning and teaching environments in the universities. Gbore (2013) also selected his respondents from six different universities which operated in heterogeneous learning and teaching environment. The study might not have produced reliable results. The selection of 50 males and 50 females from each of the six universities could also have introduced some elements of bias.

\subsection{Homogeneous Social Environment}

Barrow et.al., (2009), argue that, the factors on a single institution had the merit of reducing institutional heterogeneity and allowed the inclusion of locally held data on disabilities. They opined that, the result offered facts that can be mirrored in other universities with similar environment but suggested that, any generalizations to the broader university student population required circumspection.

\subsection{Learning and teaching environment}

Class size could play significant effect in teaching and learning. Heinesen (2010) reported that large class size had 
negative effects on the performance of students.

\subsection{Introducing other extraneous Factors.}

Ferguson et al., (2002) found that the students in private schools of nursing performed better than those studying in the public schools of nursing, the cause of which they attributed to the disparity of facility and academia resources available in the schools with the private schools having better facilities.

\subsection{Absenteeism in classes}

Devadoss and Foltz (1996) had observed that absenteeism in classes had affected students' performance. Supporting the causal factor espoused by Woodfield and Earl-Novell (2006), Devadoss and Foltz (1996) and Durden and Ellis, (1995), reported that absenteeism had affected students' academic performance. They found that student who missed classes performed poorly compared to those who attended classes regularly. Although, this had been found to be true, in $A B \cup A D$, it was not used as part of the parameters in this study.

\subsection{Gender}

There has been no consensus on the effect of gender on academic performance. While Borde (1998) found no evidence to support academic performance being influenced by gender, Woodfield and Earl-Novell (2006) and Richardson, 1994) agreed that female students outperformed male students. They attributed this partly to the facts that female students were more conscientious and were less likely to miss lectures. Barrow et al (2009) found that, the female performed better than the male and noted female advantage in the first class. Emaikwu, (2012) reported statistical significant difference in the mean academic achievement of male and female students with the mean academic achievement of male students being higher than that of their female counterparts irrespective of the mode of admission into the university

\section{Materials and Method}

All the 134 pioneer students of ABUAD that registered for the four year programmes in the pioneer Colleges of Science and Social and Management Sciences constituted the population. The 103 students that completed their programmes of study and graduated at the end of the minimum four year period formed the sample used for the study. Thirty one students constituting $23.13 \%$ were lost to transfers and attrition. Data materials were collected from the students' record files and academic records.

The SPSS V 16 software was used to analyse the data. Scatter graphs of the admission variables were plotted against the CGPA and the line of best fit was drawn for each plot. The correlation coefficient was computed for each line. The bi-variate correlation matrix of all the admission variables and CGPA was computed as well. Descriptive statistics were used to explain other relationships.

\subsection{Results and Discussion of Findings}

Table 2 shows the correlation coefficient matrix for the six variables considered with 0.05 level of significance. Table 3 shows the ranking of the correlation coefficients of the variables.

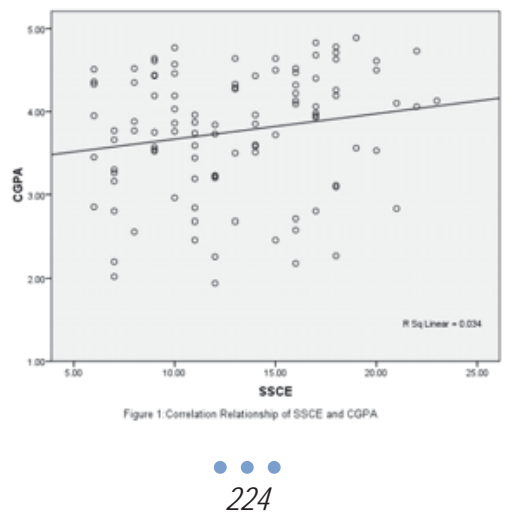




\subsubsection{Correlation between SSCE and CGPA}

Figure 1 showed the graphical relationship which was reinforced by the correlation matrix table 2. They showed significant positive relationship with correlation coefficient of 0.183 . The Secondary School Certificate Examination score is the admission requirement that best predicted students' performance at the final year. The better their SSCE score, the better their CGPA result.

Table 2: Bivariate Correlation Matrix of all the Variables

\begin{tabular}{|l|l|c|c|c|c|c|c|c|}
\hline & & SSCE & UTME & PUTME & WGHTAV & AGE & GENDER & CGPA \\
\hline SSCE & Pearson Correlation & 1 & & & & & & \\
\hline UTME & Pearson Correlation & 0.146 & 1 & & & & & \\
\hline PUTME & Pearson Correlation & -0.023 & -0.379 & 1 & & & & \\
\hline WGHTAV & Pearson Correlation & 0.064 & 0.025 & 0.896 & 1 & & & \\
\hline AGE & Pearson Correlation & -0.074 & 0.144 & -0.114 & -0.093 & 1 & & \\
\hline GENDER & Pearson Correlation & -0.005 & -0.067 & 0.153 & 0.143 & 0.019 & 1 & \\
\hline CGPA & Pearson Correlation & 0.183 & -0.177 & 0.132 & 0.115 & -0.222 & 0.100 & 1 \\
\hline & & SSCE & UTME & PUTME & WGHTAV & AGE & GENDER & CGPA \\
\hline
\end{tabular}

Source: Computed by Author

Table 3: Ranking of the Predicting Variables in the order of Correlation with CGPA

\begin{tabular}{|l|c|c|c|c|c|c|}
\hline \multicolumn{1}{|c|}{ Ranking } & 1 & 2 & 3 & 4 & 5 & 6 \\
\hline Predicting Variables & SSCE & PUTME & WGHTAV & GENDER & AGE & UTME \\
\hline Correlation oefficient & 0.183 & 0.132 & 0.115 & 0.100 & -0.222 & -0.177 \\
\hline
\end{tabular}

Source: Computed by Author

\subsubsection{Correlation between UTME and CGPA}

Correlation between UTME and CGPA showed a negative relationship with the correlation coefficient of 0.177 which is also significant (figure 2 and Table 2). The universal tertiary and matriculation examination (UTME) score is an unreliable parameter for admission. The negativity of the correlation coefficient value showed that those students with low UTME score performed better in their degree CGPA than those with higher UTME score at admission stage.

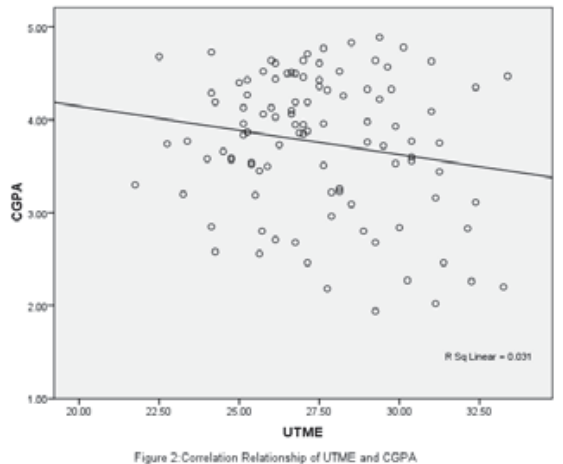

\subsubsection{Correlation between PUTME and CGPA}

Correlation between PUTME and CGPA showed significant positive correlation of 0.132 (figure 3 and table 2). The Post UTME score was the next best to SSCE which predicts the performance of the student at the final examination. 


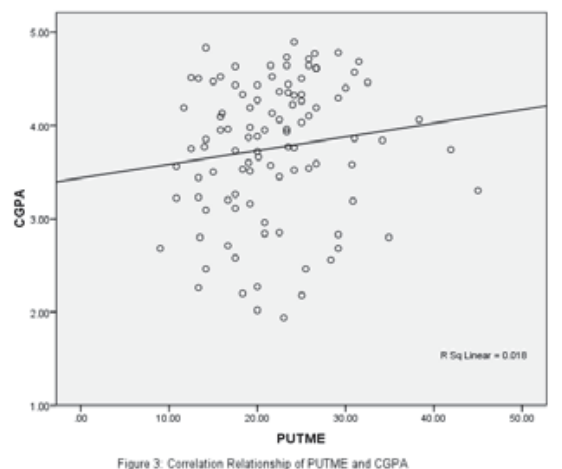

\subsubsection{Correlation between WGHTAV and CGPA}

Correlation between WGHTAV and CGPA showed significant positive correlation of 0.115 (Figure 4 and Table 2). The positive effect of the PUTME had significant effect on the negative correlation of UTME to the extent that the WGHTAV correlation coefficient became positive.

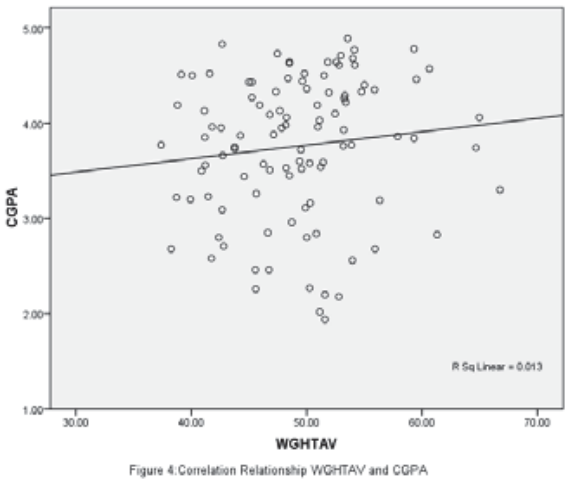

\subsubsection{Correlation between AGE and CGPA}

Correlation between AGE and CGPA showed significant negative correlation of 0.222 (Table 2 and Figure 5). This implies that the younger students performed better than the older ones. It was found that some of the students above the age of 18years had attended some other tertiary institutions briefly before coming to ABUAD.

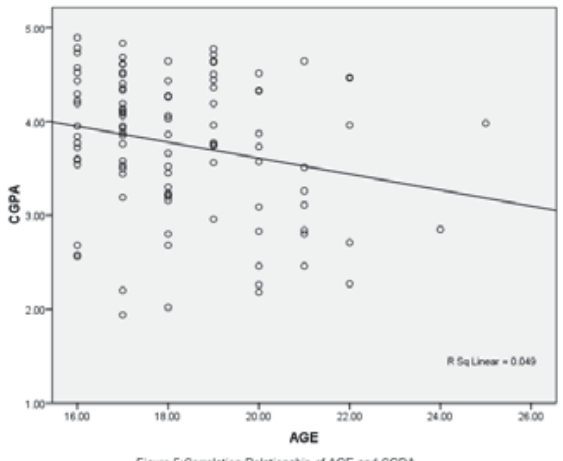


The minimum, maximum and mean ages of the students admitted were; 16,25 and 18.24 years respectively with 1.94 standard deviation. Ninety eight percent of the students were admitted within the age of 16 and 22 years. See tables 4 and 5.

Table 4: Descriptive Statistics of Age

\begin{tabular}{|c|c|c|c|c|}
\hline Student Population & Minimum Age & Maximum Age & Mean Age & Std. Deviation \\
\hline 103 & 16.00 & 25.00 & 18.2427 & 1.93759 \\
\hline
\end{tabular}

Source: Computed by Author

Table 5: Age Frequency Distribution

\begin{tabular}{|c|c|c|c|}
\hline Age & Frequency & Percent & Cumulative Percent \\
\hline 16 & 19 & 18.4 & 18.4 \\
\hline 17 & 27 & 26.2 & 44.7 \\
\hline 18 & 18 & 17.5 & 62.1 \\
\hline 19 & 14 & 13.6 & 75.7 \\
\hline 20 & 11 & 10.7 & 86.4 \\
\hline 21 & 7 & 6.8 & 93.2 \\
\hline 22 & 5 & 4.9 & 98.1 \\
\hline 24 & 1 & 1.0 & 99.0 \\
\hline 25 & 1 & 1.0 & 100.0 \\
\hline Total & 103 & 100.0 & \\
\hline
\end{tabular}

Source: Computed by Author

As shown in figure 7, the performance of the students aged 16 and 19 performed better than those aged 21 and 22 . Those above 22 performed badly.
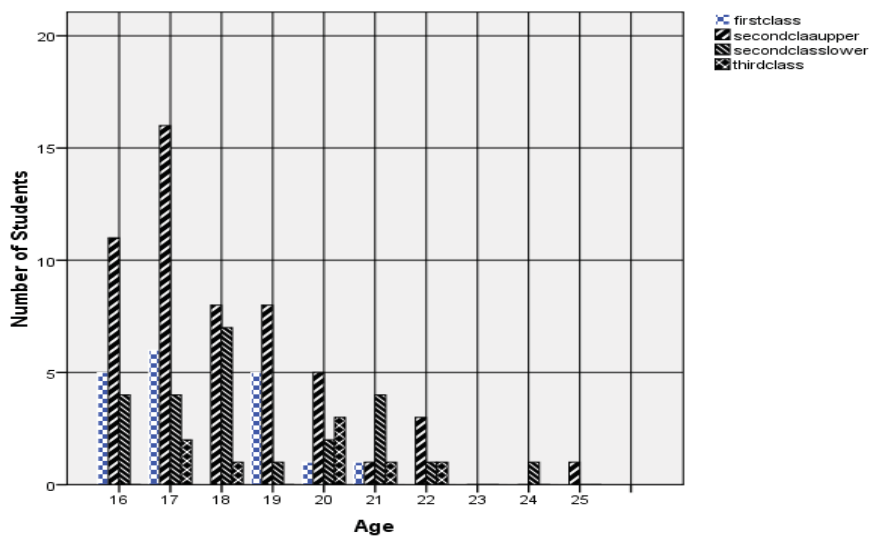

Figur 7: Class of degree Distribution by Age

\subsubsection{Correlation between GENDER and CGPA}

Although gender was not a necessary condition for admission, it was nonetheless tested to evaluate its effect on CGPA and it was found to have significant relationship with CGPA of correlation coefficient of 0.10 (Table 2). The female students which constituted $48.50 \%$ of the population performed better than their male counterparts as shown in figure 6 . 


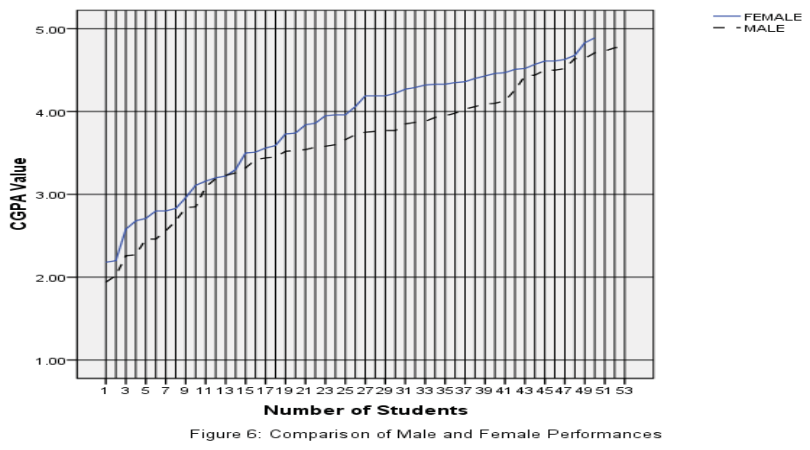

\section{Conclusion and Recommendations}

The work has shown that, SSCE is the most reliable factor that should continue to be a compulsory requirement for admission. This is in agreement with WAEC (1992) which recommended the use of SSCE for admission because of its significant relationship with students' performance in their degree examinations.

The managers of the UTME must evaluate the integrity of the examination as this work confirmed the position of Alonge (1998) who opined that the use of UTME scores for the selection of best candidates for admission into the degree programmes were deceptive because the format of UTME did not provide a reliable test of candidates coupled with poor administration of the examination which was bedeviled with malpractices among the UTME candidates.

Since UTME is a bad predictor, yet it is government compulsory requirement for admission into the first year programmes of all universities, universities should continue to combine the UTME and the PUTME using the weighted average of the combination, as it was done in ABUAD. However, taking cognizance of its negative effect as a predictor, less weight should be assigned to UTME value in the computation of the weighted average. The SSCE is reliable and should continue to be the major requirement for consideration for admission.

The NUC had placed the minimum age for admission at 16years but no restriction in the maximum age. ABUAD mission is to reform education and for it to lead by example. This study revealed that, the younger students, 16 to 19 years performed better than the older ones and the older students were more involved in disciplinary actions. It is recommended that ABUAD should reduce its maximum age limit to 22 years which captured $98 \%$ of the population.

\section{References}

Ajogbeje Oke James and Borisade Fidelis Tunde (2013), Cognitive Entry Characteristics and Semester Examination Scores as Correlates of College Students' Achievement in Mathematics. British Journal of Education, Society \& Behavioural Science 3(4). 478-489. Sciencedomain international

Alonge M.F. (1998), Implication of Probabilistic Models of Item Analysis to Educational Evaluation. Journal of Education Research and Evaluation vol. 2. Pp. 50-56.

Barrow Michael, Barry Reilly and Ruth Woodfield (2009), The Determinants of Undergraduate Degree Performance: How Important is Gender? British Educational Research Journal Vol. 35, No. 4, August 2009, Pp. 575-597.

Borde, S. F. (1998), Predictors of Student Academic Performance in the Introductory Marketing Course. Journal of Education for Business, 73 (5), Pp. $302-307$.

Devadoss, S., \& Foltz, J. (1996), Evaluation of Factors Influencing Students' Attendance and Performance. American Journal of Agricultural Economics, 78(3), Pp $499-507$.

Diaz, A. L. (2003), Personal, Family, and Academic Factors Affecting Low Achievement in Secondary Schools. Electronic Journal of Research in Educational Psychology and Psychopedagogy, 1(1), Pp43- 66.

Durden, G.C. \& Eclis, L.V. (1995), The Effects of Attendance on Students' Learning Principles of Economics. American Economics Review, 85(2): Pp. $143-146$.

Emaikwu, Sunday Oche (2012), Assessment of the Impact of Students' Mode of Admission into University and their Academic Achievement in Nigeria. International Journal of Academic Research in Progressive Education and Development July 2012, Vol. 1, No. 3 ISSN: 2226-6348. Pp. 151- 164.

Ezema, T.U (2006), A Comparison of the degree results of two-year and four-year students of business education, with implication for programme planning: A case study of University of Nigeria of Nuskka. Unpublished Thesis of University of Nigeria, Nuskka.

Ferguson E, James D, Madeley L. (2002), Factors Associated with Success in Medical School: Systematic Review of the Literature. BMJ 2002; doi.http://dx.doi.org/10.1136/bmj.324.7343.952.Pub 20 April 2002. 
Gbore, L.O. (2013), Relationship between Cognitive Entry Characteristics and the Academic Performance of University Undergraduates in South West, Nigeria Journal of Educational and Social Research Vol. 3 (1) Pp. 19-24.

Heinesen, E. (2010), Estimating Class-Size Effects using Within School Variation in Subject-Specific Classes. Economic Journal, 120(545), Pp. $737-760$.

JAMB, (1978), Joint admission and Matriculation Board Act No. 2 of 1978 of the Federal Military Government, 13"h February, 1978.

Kolawole, E. B., I. O. Oginni, E. O. Fayomi (2011), UTME And POST-UTME as Predictors of Students' Academic Performance in Chemistry in Nigerian Universities. International Journal of Sustainable Development Vol.2, No.9. Pp23-28.

Lawal, Yekini Olawaiye (2013), Education as an Instrument for Effective National Development: Which Way Nigeria. Business \& Entrepreneurship Journal, vol.2, no.2, 2013, 27-38, ISSN: 2241-3022 (print version), 2241-312X (online). Scienpress Ltd.

NUC, (2012), National Universities Commission (NUC) Benchmark Minimum Academic Standard (BMAS).

NUC, (1985), National Universities Commission Decree (Act) No. 16 of 1985 as amended by Decree (Act) No. 48 of 1988.

Ogbebor, Godwin Gideon (2012), Mode of Admission and Undergraduate Academic Performance: A Comparative Study in Delta State University. Journal of Educational and Social Research Vol. 2 (3) ISSN 2240-0524 September 2012 Pp195-204

Osakuade, Joseph Oluwatayo (201), Effectiveness of University Matriculation Examination and Post-University Matriculation Examination on the Academic Performance of Nigerian Undergraduate Students. Journal of Education and Practice. Vol 2, No 4, 2011. Pp. 59-65. ISSN 2222-1735 (Paper) ISSN 2222-288X (Online).

Parveen Azam Ali (2008), Admission Criteria and Subsequent Academic Performance of General Nursing Diploma Students (JPMA Vol. 58, No. 3, March 2008 128-132

Richardson, J. T. E. (1994), Mature Students in Higher Education: Academic Performance and Intellectual Ability. Higher Education, 28(3), Pp. $373-386$.

WAEC, (1992), The Senior School Certificate Examination as A Predictor of University Performance. West African Journal of Education 2. Pp 112-117. Yaba-Lagos.

Woodfield, R., \& Earl-Novell, S. (2006), An Assessment of the Extent to Which Subject Variation in Relation to the Award of First Class Degree Between the Arts and Sciences Can Explain the 'Gender Gap'. British Journal of Sociology of Education, 27(3), Pp. 355 -372 . 
